\title{
Flexible training in optics and photonics: an open window towards a modern society
}

\section{Clementina Timus}

Clementina A. Timus, "Flexible training in optics and photonics: an open window towards a modern society," Proc. SPIE 9664, Ninth International Topical Meeting on Education and Training in Optics and Photonics, 966405 (24 October 2005); doi: 10.1117/12.2207537

SPIE Event: Ninth International Topical Meeting on Education and Training in Optics and Photonics, 2005, Marseille, France 
Ref ETOP005

\title{
Flexible training in Optics and Photonics an open window towards a modern society
}

\author{
Clementina A. Timus \\ National Institute for Laser, Plasma and Radiation Physics \\ P.O.Box MG-36, Magurele-Bucharest, Romania \\ e-mail: timus@ifin.nipne.ro
}

\begin{abstract}
Characteristics of the education in optics in Romania in the last 15 years are discussed in a comparative way from a traditional system to the new ever changing proposals. The discussion concerns the situation in the previous time and recently, comments and problems to be solved. There is a recession all around the world as concerns the choice for a career in science and this is what we have to think about and try to find, what to do?

This is not new that Romania continues to offer qualified work force for other countries, as the best students leave for western or US universities. In the former time physics and electronics were the faculties, which attracted the option of the best students, as the career in science and high level education was of high prestige. The things are different now, when there are other more attractive careers as business, show biz, media etc.
\end{abstract}

\section{Key words}

optics in Romania, education, scientific activity, complementary policies, project, Bologna declaration, qualified work force, private system of education, responsibility, professionalism, coordination, cooperation, respect, brain drain, migration quality of life,

\section{Summary}

This talk tries to discuss from the point of view of the scientist involved in the research activity, based on its experience as project coordinator, team leader, its task in the continuation of the education regarding the formation of young scientists.

The author's experience as regards the education in optics resulted, besides the scientific activity, from the academic one with last year students from the Physics Faculty, the participation in the organization of the module franco-phone with the ENSAIS (Ecole Normale Superieure d'Art et Inginerie de Strasbourg) member in the organization of the International Conference of Optics ROMOPTO, advisor professor for Romania SPIE Student Chapter, the activities in the frame of the civil society.

The last 15 years due to the liberalization of the relationships in all the fields, the science included, the possibility to develop mobilities and working stages in the laboratories from the western countries, to confront the education level from an Eastern European country to the level in western countries, represented new challenges that deserve to be discussed and considered.

In the field of science and research the European Union is creating the European Research Area. ERA is a broad vision for research in Europe aimed to lead at better 
coordination, more cooperation and improved complementary policies and programmes of all relevant participants. The EU's final objective is to contribute to the competitiveness of European industry and improve the quality of life of its citizens.

The moment of the unified Europe is not far so it's pretty time to think to the common language we'll speak very soon; this language is not, of course, English, French, German or others but the common scientific language according the common accepted rules. There are many different countries in Europe each having its own traditions, rules, experience, good or bad, it depends on the commonly accepted system of reference.

For many years in the time of the cold war the investment in science was justified because of the concurrence between the two political systems and the suspicion between them was the force to push the things forward. The science was a field of high prestige and justified priority in investment.

Is the present system of investment in science more efficient? We spend a lot of time to finish a project, to be submitted and evaluated according established criteria and this lasts sometimes quite long time till the project is selected for financial support, not always the teams of scientists could match and accomplish complementary activities. Not always the time spent for real scientific activities is sufficient, as new projects have to be prepared in order to assure the continuation of the scientific process. Very often the feeling of a virtual and not real activity is a done. A lot of people complain because the majority of time is spent for bureaucracy and not real scientific activity; seems to be a virtual and not a real activity. This is not to regret the old times but probably there are too many changes and the system is not yet the optimal one.

When I was young, I spent almost all the time in the laboratory, in front of the instruments, evaluating and comparing results, trying to deeper know the magic of the phenomenon, the dialectic report between cause and effects ; now people is discovering the magic of the computer and, for sure, we can't any more think science without it. Now almost all the time is spent before the computer to prepare projects, or write reports and financial reports....

The people we educate, I mean our young colleagues are not so obedient as probably we have been as young scientists at the beginning of our career, so we do not represent a model for the majority of them, they want to be themselves, they have stronger personalities, become faster matures and are able to move faster then us, as the concurrence, the pride of young people, their flexibility are qualities to assure the success. Young people have to be financially motivated to be involved in the scientific activity, but this kind of activity doesn't move so fast to benefits as other kind of activities. In Romania we are looking for the capital, but capital doesn't mean only accounts in the banks, shares in the industries, oil, construction companies, but scientific, technical economical knowledge means capital, as well. This capital is the brain of scientists, engineers, administrators and other participants to the improvement process of the life of the citizens.

The education nowadays has to be very flexible, according the needs of the society, but this society will be very nonhomogeneous in the near future Europe, as the economical level is different in Europe's countries and so will be for the years. The economical level is not only the single barrier, but there are cultural differences, specific features for each people and for sure the fair competition, the complementarities, the respect for the real values have to be the background of the education in Europe and all around the world, in order peoples be able to construct a better life on Terra. 
The Declaration of Bologna (make compatible the education system in each country with the European one) is applied since this year in Romania, but there are countries in which the system is very much controversial.

On the occasion of the visit in Bucharest of some representatives from the Department of Fundamental Studies from the Center of European Studies of Strasbourg (Laurent Mace and Roger Francois Gauthier) even in France, quite a closed system (according R.F. Gauthier) to find the best solutions of education is an interest in progress; the results are to be expected in the years to come. I hope all together, having better knowledge about each other's expertise could contribute to find the best ways to improve the education in general, in optics particularly.

I think it is necessary all the specialists to think in the market economy spirit and in this respect the curricula have to be established according to such imperatives.

The students in science and engineering have to receive an education much closer to the practical activities and to develop activities not only in the very low endowed laboratories from the physics faculties, but be engaged in complex teams with senior scientists.

The prospect of young scientists and PhD students to work in the frame of EU or NATO projects is a good opportunity to increase their expertise and the responsibility. Unfortunately to be lucky to have the support for such a project is a very long and hard work and very time consumption.

The students have to be stimulated to take their own responsibilities in the scientific process by direct involvement in the design, realization and characterization of some products. The report is an important step in the scientific education and in this respect the participation in the seminaries, international conferences is a need.

There is no more pure sciences but rather interdisciplinary ones and in this respect the expertise has to be extended to cover knowledge upon several branches. In the last years new curricula have been proposed but not really necessary and connected to the practical activities. Not all the students develop activities for which they are educated but different others. The rigor of education is much less than in the former time, when there were much limited opportunities. This doesn't mean we complain the former time as political system but the organization was more serious and the knowledge deeper than today.

It is necessary in my opinion a closer communication between the universities and the high schools, the future students to be able to take the good decisions for their profession according their real skills.

The population is decreasing more and more there are less young people candidate for high education and too many teachers who fight to keep their chairs making compromise to the quality. The liberalization of the education in Romania had as a consequence a huge increase of the private education system using the same professors from the traditional universities; such universities have higher financial possibilities and could move easier. Unfortunately there are too many private universities in unknown places who produce university titles for many politicians or business people, who afford to pay for such titles.

The most serious phenomenon, with which is confronted Romania and many other countries, as well, is the brain drain, the migration of high qualified people to US or western countries for better working conditions and higher incomes. Generally $\mathrm{PhD}$ students accepts jobs in the host countries and do not return back. There are fields in 
the national economy, where the activity had been stopped, or new jobs, interdisciplinary ones are not yet available. A better coordination could be a solution.

Romania is one of the country, with best results concerning the participation scholars in the international contexts in mathematics, information, physics and chemistry and many of them are invited to continue the education in US universities.

Unfortunately, the politics is too important nowadays and not the real expertise.

This conference could be an opportunity for all of us to find better solutions to improve the education in optics, to assure a real continuation of the education process in a context close to the needs of the modern society, based on professionalism, respect and open mind.

This could be the proposal for the future language of the Unified Europe. 